\title{
THE ANALYSIS AND THE DESIGN OF E-MARKETING STRATEGY AT SME'S (A CASE STUDY: THE DARE TO DREAM INDONESIA COMMUNITY)
}

\author{
Henkie Ongowarsito; Kartika Nurcahyani; Brata Wibawa Djoyo \\ Faculty of Information System Management, Double Majors Faculty, \\ Bina Nusantara University J1 KH Syahdan 9, Jakarta 11480, Indonesia
}

\begin{abstract}
The purposes of the research are to analyze the e-marketing strategy and to design e-marketing application which is a website that is appropriate for SME'S of Dare to Dream Indonesia (D2DI) community. The methodology of analysis used consists of 4 stages from 7 stages of e-marketing and the design method consists of three last stages of e-marketing. The result achieved is a website as an e-marketing application that can support marketing and promoting activities, expanding the target market, giving complete information and facilitating the customers to access product information, and supporting the communication between D2DI community, SME'S, and the customers. The conclusions obtained are that e-marketing can be a solution to solve customer needs of the availability of complete and current information and communication.
\end{abstract}

Keywords: Information System, content management system, academic development

\section{INTRODUCTION}

Along with the development of time that is supported by technological advancement, the public, especially in Jabodetabek area, has formed various kind of communities. The members of the Dreamers help each others to achieve dreams, aspirations, and goals that in line with the visions of their lives, so that they can achieve all the potentials of themselves. Not only dreams, but they achieve it with the right planning. To ease the development of Dare to Dream Indonesia community (D2DI), marketing via the internet media really needs an e-marketing. E-marketing uses a network technology to conduct a market research and product development, the development of a strategy and the tactics to persuade customers to buy, to provide online distribution, to keep the customer records, to lead the customer satifaction service, and to collect the feedback from the customers, so the result can be reviewed continually and the process is more effisient and effective. The goals of website-marketing application that combines a variety of information technology is: to make a change in marketing strategy to gain customers' values through segmentation; to create a change to satisfy the customers; to create plans; and to ripen the concept so that it simplify promotions and others [1]. Every SME'S helped by D2DI, must have problems. There are the same kind of problems, and there are also different kinds from any other SME'S. The problems faced by D2DI members, among others, about the commitment, lack of competitiveness in the public; looking for a market and markets the SME'S product; customers find difficult to get more detailed information about the product; lack of communication created between D2DI, SME'S, and the customers. The scopes in this research are: (1) The development of website-based application for D2DI. (2) This research devoted to micro, small, and medium businesses that has become the member of D2DI. (3) This research devoted to the member who already has a business. (4) The design of the website focused on promotional activities. (5) Website-marketing planning dicuss neither about the process of product reservations, the payment, and the product delivery nor everything that is related to those things.

\section{METHOD}

\section{Analysis Method and Design Method \\ The analysis method is conducted using four early stages of seven e-marketing planning stages, according to Ref. [2], which are: (1) Situation Analysis by conducting the anlaysis of Strengths, Weaknesses, Opportunities, dan Threats (SWOT) from D2DI community. (2) E-marketing Strategic Planning. (3) Objectives. (4) E-marketing Strategy. The SWOT analysis is conducted by calculating the result of ratings and the scale of external factors (EFE) and internal factors (IFE) of \\ D2DI community which is then recapitulated into Internal-External matrix [3].}


Meanwhile, the interface website design method uses seven stages of e-marketing planning from the theory of 7c's from Ref. [4], which is in designing a web site, it is wise to see these following elements: (1) Context. (2) Content. (3) Community. (4) Customization. (5) Communication. (6) Connection. (7) Commerce.

\section{RESULT AND DISCUSSION}

\section{Situation Analysis}

Dare to Dream Indonesia (D2DI) is a Community Base Indonesia which is initiated by PT Mitra Rencana Edukasi (MRE) of Financial and Business Advisory as the part of Corporate Social Responsibility. D2DI is an initiative movement that actualizing the Indonesians' dreams.

Based on the result of EFE calculation from D2DI community, a value worth 3.29 is obtained, shows that D2DI has a good response against the opportunity, and avoid the threat in today's industry because it is above 2.5 (the average value is 2.5 ). In table 1, the most important opportunity in determining the success is "there is a development of information technology (IT)" with 0.72 of value. Meanwhile, the biggest threat is "more business communities" with 0.64 of value.

Based on the IFE table of calculation, a value worth 3.67 is obtained, which means that D2DI community has a strong internal position because it is above 2.5 (the average value is 2.5 ). Table 1 shows that the strong factor of D2DI is "D2DI's ability about educating the members about entrepreneurship and finance using easy language without reducing the quality of the information about the theory" with 0.45 of value, meanwhile for the weakness, the same value, which is 0.21 , is obtained from every available weaknesses.

Based on the result of the Competitive Profile Matrix, D2DI community placed in the last position (fourth) as it compared to the rivals. It is shows that D2DI community has not provided the best service if it is compared with the rivals, especially from the method and also the quality (see Table 2).

Table 1: SWOT Analysis

\begin{tabular}{|c|c|}
\hline D2DI Strengths : & D2DI Weakness : \\
\hline $\begin{array}{l}\text { The ability of D2DI to educate the members about } \\
\text { entrepreneurship and finance using an easy language } \\
\text { without reducing the quality of the information about } \\
\text { the theory (S1) } \\
\text { The procurement of D2DI activities to strengthen } \\
\text { the relationship between the members and also to } \\
\text { increase the members' knowledge (S2) } \\
\text { Incorporated in the same vision and mission so it can } \\
\text { be in the same direction with each of the members } \\
\text { (S3) } \\
\text { Having cooperation with various parties (S4) } \\
\text { As a forum of developing the members to make them } \\
\text { aware of business and technology (S5) } \\
\text { Members are helped to achieve their dreams (S6) } \\
\text { Can be used as a sharing place for many things, } \\
\text { especially in business (S7) }\end{array}$ & $\begin{array}{l}\text { - There has been no organizational structure (W1) } \\
\text { - } \quad \text { ack of commitment in D2DI members to run the } \\
\text { business (W2) } \\
\text { Lack of the team from the community so it is quite } \\
\text { difficult to manage activities (W3) } \\
\text { Lack of scheduling preparation to the procurement } \\
\text { of D2DI activities (W4) } \\
\text { Lack of competitiveness that happens between the } \\
\text { SME'S members (W5) } \\
\text { If there is one member who has low energy, then it } \\
\text { will affect the other members (W6) }\end{array}$ \\
\hline Opportunity in D2DI : & Threat in D2DI : \\
\hline $\begin{array}{l}\text { - There is a development of information technology } \\
\text { - } \mathrm{O} 1) \\
\text { The increase of the number of internet users in } \\
\text { Indonesia }(\mathrm{O} 2) \\
\text { The opportunity of market expansion both in the } \\
\text { country or abroad (O3) }\end{array}$ & 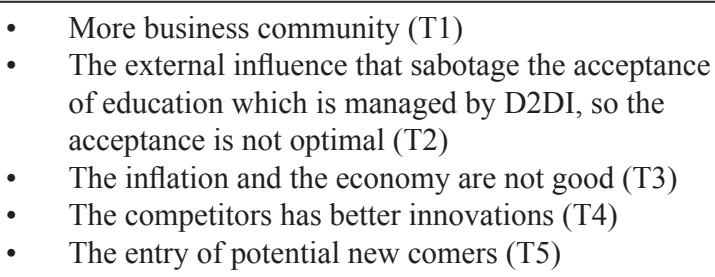 \\
\hline
\end{tabular}


Table 2: CPM Matrix

\begin{tabular}{|c|c|c|c|c|c|c|c|c|c|}
\hline \multicolumn{2}{|c|}{$\begin{array}{c}\text { Decisive Factors of } \\
\text { Success Weight } \\
\text { Billing }\end{array}$} & \multicolumn{2}{|c|}{ D2DI Community } & \multicolumn{2}{|c|}{ TDA Community } & \multicolumn{2}{|c|}{$\begin{array}{c}\text { Indonesia } \\
\text { Womanpreneur } \\
\text { Community }\end{array}$} & \multicolumn{2}{|c|}{$\begin{array}{c}\text { Indonesia Organic } \\
\text { Community }\end{array}$} \\
\hline & & Rating & Result & Rating & Result & Rating & Result & Rating & Result \\
\hline Services & 0.26 & 4 & 1.04 & 4 & 1.04 & 4 & 1.04 & 4 & 1.04 \\
\hline Networking & 0.26 & 4 & 1.04 & 4 & 1.04 & 4 & 1.04 & 4 & 1.04 \\
\hline Methods & 0.26 & 3 & 0.66 & 4 & 0.88 & 3 & 0.66 & 4 & 0.88 \\
\hline Quality & 0.26 & 3 & 0.78 & 4 & 1.04 & 4 & 1.04 & 3 & 0.66 \\
\hline Total & 1.0 & & 3.52 & & 4 & & 3.78 & & 3.62 \\
\hline
\end{tabular}

The Stage of Analysis

Table 3a: SWOT Matrix

\begin{tabular}{|c|c|c|}
\hline & Strengths (S) & Weaknesses (W) \\
\hline & $\begin{array}{l}\text { - The ability of D2DI to educate the members } \\
\text { about entrepreneurship and finance using an } \\
\text { easy language, without reducing the quality } \\
\text { of the information about the theory (S1) } \\
\text { - } \quad \text { The procurement of D2DI activities to } \\
\text { strengthen the relationship between the } \\
\text { members and also increasing the members' } \\
\text { knowledge (S2) } \\
\text { - } \quad \text { Incorporated in the same vision and mission } \\
\text { so it can work in the same direction with } \\
\text { each members (S3) } \\
\text { - Having cooperation with various parties (S4) } \\
\text { - As a forum of developing the members } \\
\text { to make them aware of business and } \\
\text { technology (S5) } \\
\text { Members are helped to achieve their dreams } \\
\text { (S6) } \\
\text { Can be used as a sharing place for many } \\
\text { things, especially in business (S7) }\end{array}$ & 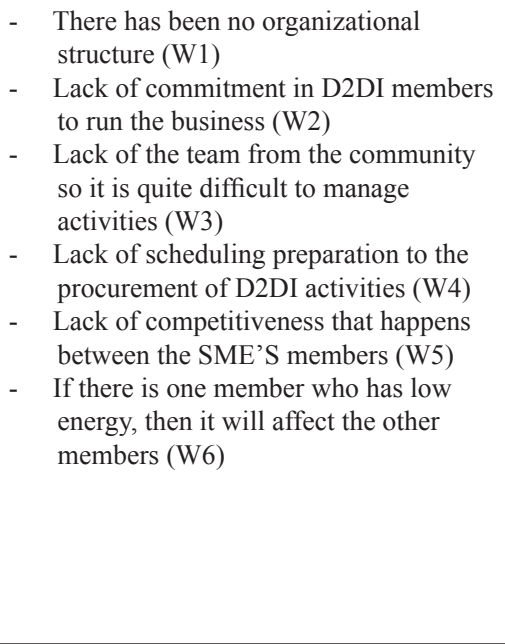 \\
\hline Opportunities (O) & SO Strategy & WO Strategy \\
\hline $\begin{array}{l}\text { - There is a development of information } \\
\text { technology (O1) } \\
\text { - The increase of the number of internet } \\
\text { users in Indonesia (O2) } \\
\text { - The opportunity of market expansion both } \\
\text { in the country or abroad (O3) }\end{array}$ & $\begin{array}{l}\text { - } \begin{array}{l}\text { Creating a market service using internet- } \\
\text { based website }(\mathrm{S} 5, \mathrm{~S} 6, \mathrm{O} 1, \mathrm{O} 2)\end{array} \\
\text { - } \quad \text { Increasing the marketing area to gain the } \\
\text { number of members (S5, O1,O3) } \\
\text { - } \quad \begin{array}{l}\text { Increasing the procurement of activities (S2, } \\
\text { S4, O2) }\end{array}\end{array}$ & $\begin{array}{l}\text { - } \quad \text { Adding the number of team to increase } \\
\text { the marketing }(\mathrm{W} 1, \mathrm{~W} 3, \mathrm{O} 3)\end{array}$ \\
\hline Threats (T) & ST Strategy & WT Strategy \\
\hline $\begin{array}{l}\text { - More business communities (T1) } \\
\text { - The external influence that sabotages } \\
\text { the acceptance of education which is } \\
\text { managed by D2DI, so the acceptance } \\
\text { is not optimal (T2) } \\
\text { - The inflation and the economy are not } \\
\text { good (T3) } \\
\text { - The competitors has better innovations } \\
\text { (T4) } \\
\text { The entry of potential new comers } \\
\text { (T5) }\end{array}$ & $\begin{array}{l}\text { - Improving the level of quality and } \\
\text { services (S1, S5, T2, T4, T5) } \\
\text { - Promoting the excellences of the } \\
\text { products and services, that owned by } \\
\text { the community, to the public (S5, S6, } \\
\text { T1) } \\
\text { - Providing educations via online or } \\
\text { offline (S1, T2) }\end{array}$ & $\begin{array}{l}\text { - Increasing the preparation of the } \\
\text { activities that will be conducted } \\
\text { (W4, T1) } \\
\text { - Motivating the members to be more } \\
\text { energetic (W5, W6, T2) }\end{array}$ \\
\hline
\end{tabular}




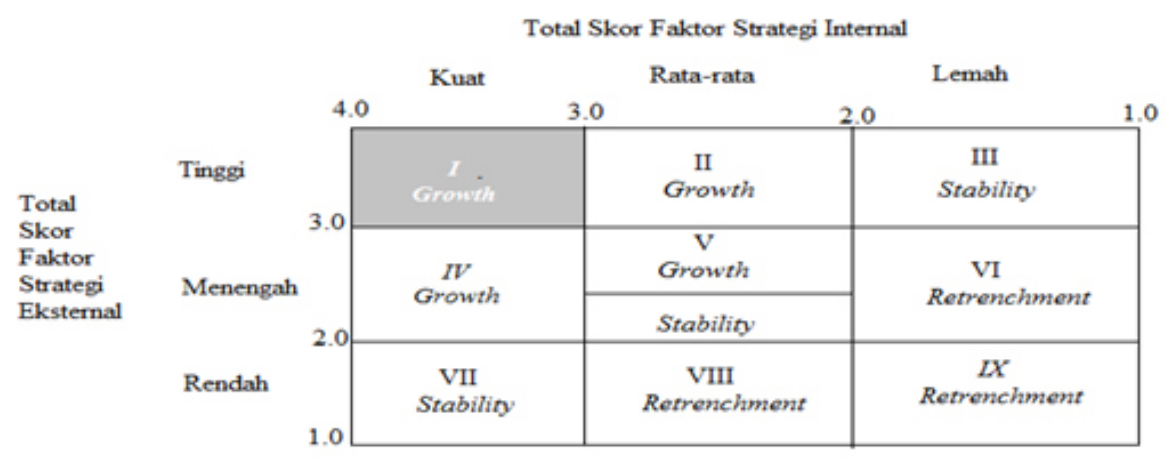

Keterangan

Sel I, II, IV : Pertumbuhan dan Membangun

Sel III, V, VII : Pertahankan dan Pelihara

Sel VI, VII, XI : Panen atau Divestasi

Fig 1: The Internal and External Matrix

According to the calculated result in IE Matrix analysis, D2DI community is at the quadrant 1 (See Fig. 1), which means that the community is undergoing growth. It is based on the calculation of table EFE, which is 3.29 and table IFE, which is 3.67. For this quadrant, the suitable strategy is the intensive strategy, such as market penetration, product development, and market development. Or the use of fore and horizontal integrative strategy. This integration strategy is the strategy to perform mastery over distributor suppliers, and competitors.
The fore integration is the strategy to improve controls on distributor, and horizontal integration is the strategy to control the competitors.

Table 4 is the result of the analysis of alternative strategy on QSPM matrix, the obtained result is the market penetration strategy can be considered to be the alternative strategy for D2DI community. By using QSPM matrix, it can be chosen one of the strategies that considered the most appropriate to the D2DI community.

Table 4: QSPM Matrix

\begin{tabular}{|c|c|c|c|c|c|}
\hline \multirow[b]{2}{*}{ The Factors of Internal Strategy } & \multicolumn{3}{|c|}{ Market Development } & \multicolumn{2}{|c|}{ Market Penetration } \\
\hline & Weight & Rating & Result & Rating & Result \\
\hline \multicolumn{6}{|l|}{ Strength } \\
\hline $\begin{array}{l}\text { The ability of D2DI to educate the members about entrepreneurship } \\
\text { and finance using an easy language, without reducing the quality of the } \\
\text { information about the theory }\end{array}$ & 0.09 & 4 & 0.36 & 4 & 0.36 \\
\hline $\begin{array}{l}\text { The procurement of D2DI activities to strengthen the relationship between } \\
\text { the members and also increasing the members' knowledge }\end{array}$ & 0.09 & 3 & 0.27 & 4 & 0.36 \\
\hline $\begin{array}{l}\text { Incorporated in the same vision and mission so it can work in the same } \\
\text { direction with each members }\end{array}$ & 0.08 & 4 & 0.32 & 2 & 0.16 \\
\hline Having cooperation with various parties & 0.08 & 4 & 0.32 & 4 & 0.32 \\
\hline $\begin{array}{l}\text { As a forum of developing the members to make them aware of business and } \\
\text { technology }\end{array}$ & 0.08 & 4 & 0.32 & 4 & 0.32 \\
\hline Members are helped to achieve their dreams & 0.08 & 3 & 0.24 & 2 & 0.16 \\
\hline Can be used as a sharing place for many things, especially in business & 0.08 & 3 & 0.24 & 1 & 0.08 \\
\hline \multicolumn{6}{|l|}{ Weakness } \\
\hline There has been no organizational structure & 0.07 & 2 & 0.14 & 1 & 0.07 \\
\hline Lack of commitment in D2DI members to run the business & 0.07 & 3 & 0.21 & 2 & 0.14 \\
\hline $\begin{array}{l}\text { Lack of the team from the community so it is quite difficult to manage } \\
\text { activities }\end{array}$ & 0.07 & 2 & 0.14 & 2 & 0.14 \\
\hline Lack of scheduling preparation to the procurement of D2DI activities & 0.07 & 3 & 0.21 & 4 & 0.28 \\
\hline Lack of competitiveness that happens between the SME'S members & 0.07 & 2 & 0.14 & 3 & 0.21 \\
\hline $\begin{array}{l}\text { If there is one member who has low energy, then it will affect the other } \\
\text { members }\end{array}$ & 0.07 & 2 & 0.14 & 3 & 0.21 \\
\hline IFE Total & 1.00 & & 3.19 & & 2.81 \\
\hline
\end{tabular}


Table 4: QSPM Matrix (continued)

\begin{tabular}{|c|c|c|c|c|c|}
\hline \multirow[b]{2}{*}{ The Factors of Internal Strategy } & \multicolumn{3}{|c|}{ Market Development } & \multicolumn{2}{|c|}{ Market Penetration } \\
\hline & Weight & Rating & Result & Rating & Result \\
\hline \multicolumn{6}{|l|}{ Opportunity } \\
\hline There is a development of information technology (IT) & 0.18 & 1 & 0.18 & 4 & 0.72 \\
\hline The increase of the number of internet users in Indonesia & 0.16 & 2 & 0.32 & 4 & 0.64 \\
\hline The opportunity of market expansion both in the country or abroad & 0.18 & 1 & 0.18 & 3 & 0.54 \\
\hline Opportunity Total & & & 0.68 & & 1.9 \\
\hline \multicolumn{6}{|l|}{ Threat } \\
\hline More business communities & 0.16 & 1 & 0.16 & 3 & 0.48 \\
\hline $\begin{array}{l}\text { The external influence that sabotages the acceptance of education which is } \\
\text { managed by D2DI, so the acceptance is not optimal }\end{array}$ & 0.05 & 3 & 0.15 & 1 & 0.05 \\
\hline The inflation and the economy are not good & 0.11 & 1 & 0.11 & 1 & 0.11 \\
\hline The competitors has better innovations & 0.09 & 1 & 0.09 & 4 & 0.36 \\
\hline The entry of potential new comers & 0.07 & 1 & 0.07 & 3 & 0.21 \\
\hline EFE Total & 1.00 & & 1.26 & & 3.11 \\
\hline Total Nilai Daya Tarik & 2.00 & & 4.45 & & 5.92 \\
\hline
\end{tabular}

\section{The Ongoing Process of Marketing}

The process of business on D2DI is: (1) The staffs from D2DI or PT. MRE are proposing cooperation with universities or corporations to be able to hold activities together and facilitated by a joint. (2) If the universities or corporations are interested in cooperating with D2DI, there is going to be further talks about the activities that will be conducted, such as about time, the subject, the speaker, the place and the consumption. (3) After both of the parties agreed, then D2DI party do the dissemination of informations about the activities on Facebook, Twitter, and E-mail, especially to D2DI's members. (4) If it is unclear, the public can ask for informations on Facebook, Twitter, E-mail, or even to the contact person. (5) If the public or D2DI's members are interested with the activities, then members or the public can contact the contact person or send E-mail to D2DI to do the registration. (6) The public or members can also recommend D2DI activities to friends or family via social media or other ways. (7) If there is a confirmation from D2DI party, then members and the public can come directly to the event to do the D2DI activities.

Based on Market Opportunity Analysis (MOA), several problems are obtained, are:

\section{Indentify The Needs of Customers That Has Not Been Fulfilled}

Based on the questionnaire result, which is done to the SME'S, it can be concluded that the customers are difficult to find detailed informations about the products sold by the SME'S, and lack of communication between the SME'S and the customers. The average of the SME'S sell their products through social media, such as Facebook and Twitter.
Identify A Certain Customer Who Will Be Targeted by The Community

Based on the result of data processing of the questionnaire, there are several market segmentations that will be targeted by the community, which are divided into certain identifications, which are the occasional, demography, firmography, and benefit. Occasionally, the market segment of D2DI is the SME'S which is oftenly accessing the internet (every day). Demographically, the market segment of D2DI is divided into three, which are the age, sex, and the level of expenses. In terms of age, the market segment of D2DI is they who are in age over twenty five years up to forty years.

\section{Evaluate The Profit That Is Related To The Competition}

In competition, D2DI community has competitors, either it is direct competitor, or indirect competitor. For direct competitor, D2DI community has several direct competitors, which are the "Tangan Di Atas" (TDA) community, the Indonesia Womanpreneur community, and Indonesia Organic community.

\section{Evaluate The Corporoation's Resource}

Evaluation on three kinds of D2DI community resources are: (1) Customer-facing Resources: D2DI community has a brand name, which has already been known, because D2DI has been reported in some famous media, such as okezone.com, Nova magazine, and Business Idea Magazine. (2) Internal Resource: D2DI has not had the organization structure, especially for the marketing. But, D2DI stays promoting the best service so the members can obtain those good informations from the activities 
or even with social media. (3) Upstream Resource: The relationship between suppliers and D2DI is good. It can be seen in establishing cooperation and communication, that are greatly created, between D2DI and suppliers, which is PT. MRE Financial and Business Advisory.

\section{Evaluate The Readiness of Market in Technology}

Technology Vurnerability: The major way, so that D2DI can survive and better known by the public, is to promote D2DI through social media, like Facebook and Twitter. Technology Impact: The technological change is felt strongly affecting the business process in D2DI.

\section{Determine The Opportunity in Concrete Terms}

There are various opportunities that can be utilized by D2DI, among them are: (1) Value proposition: members are helped to achieve their dreams. (2) Costumer benefits: the activities, which are conducted by D2DI, are filled by the speakers, who work as lecturers from universities, and also have businesses, so the members obtain information from the field of academic, as well as the field of business. (3) Critical resources: SME'S has good quality products. (4) Reasons to believe: with a good reputation in the public's eyes, D2DI can easily expand their marketing and trusted by the public, so the public joined with D2DI. (5) Resource sourcing: The community is helped by PT. MRE's staffs, who has experiences in the fields.

\section{Evaluate The Attractions For Customers}

From the analysis result that is conducted, it is obtained the results as follows: (1) Competitive Vulnerability: By using the website-marketing as the marketing media in D2DI community, it is expected to be a positive factor to the community. (2) Technical Vulnerability: PT.MRE's staffs, who helped D2DI, generally have been able to operate a Windows and Office-based computer, and also have the ability to access the internet. (3) Magnitude of Unmet Need: By the presence of website, which will be implemented later on D2DI community, the customers' needs, that is not yet fulfilled, can be minimized. (4) Interaction Between Segment: By the prsence of e-marketing, it is expected that the interactions between segments can be broader and more varied. (5) Likely Rate of Growth: The level of growth on D2DI community is rated positively because the growth on D2DI community, since it is invented more or less one year until today, increased. (6) Technology Vulnerability: Today, D2DI is using social media, which are Facebook and Twitter, as one form of marketing, but it has not been used as maximum as possible. (7) Market Size: Today, D2DI community has the market scope in the Jakarta, Bogor, Depokm Tangerang, and Bekasi (Jabodetabek).

\section{Planning Strategy}

In e-marketing strategy that will be used in D2DI website, there are several particular strategies, which are:

\section{Differentiation}

There are differentiation strategies that is used in online business, which are: (1) Site Environment/ Atmospherics: The website is made simply and as easily as possible, so the user (SME'S) can understand and promote their products easily. (2) Built Trust: D2DI build the public's trust by cooperating with various parties that have already been known by the public, and by conducting the activities together, then D2DI can be more trusted by the public. (3) Efficient and Timely Order Processing: The registration can be done through the website, the visitors can, easily and quickly, do the registration. (4) Pricing: If SME'S wanted to do D2DI activities, SME'S does not have to pay, they just have to do registrations and come to the D2DI activities. (5) Customer Relationship Management (CRM): The feature on D2DI website will help the website visitor to serve their needs of informations and improve D2DI's services for the public. (6) Invite User-Generated Content: On D2DI website, there is provided a feature to write a review and SME'S testimonials.

\section{Position}

Right now, D2DI is using a digital media platform and social media for marketing, such as Facebook, Twitter, and e-mail. It is expected that, by the presence of the e-marketing website, it can help the marketing so D2DI will be better known by the public.

\section{Marketing Objective}

The objectives of this marketing are: (1) Listing the SME'S on D2DI community. (2) Increasing the number of members. (3) Providing educations about entrepreneurship to the SME'S. (4) Promoting the SME'S products. (5) Strengthen the brand image. (6) Maximazing the responses given by the SME'S and website's visitors. (7) Providing detailed information about the products.

\section{E-Marketing Strategy}

Product Strategies: D2DI activities are filled by professional people in their fields. Besides the activities held by D2DI, members can also discuss through the forum. D2DI website provides a forum feature and also summaries of the activities. Pricing Strategies: If they want it, the members can also do the activities without being charged. Place (Distribution) Strategies: PT.MRE's staffs help D2DI in providing services for the members. Promotion (Communication) Strategies: The promotions on D2DI website are: (1) Website display is simply made so it is easier to SME'S to promote their products. 
(2) There is a two-ways communication between the website visitors with either D2DI or the SME'S.

(3) There is a forum feature and sharing through the social media (Facebook and Twitter) so either D2DI activities or SME'S products can be better known by the public.

Relationship Management Strategies: The strategies of management relationship consist of: (1) An increase in the number of members: With implementation of CRM, D2DI community tries to provide maximum services so the public, who is not a member yet, will soon be a member. (2) An increase in the number of participants in D2DI activities: With implementation of CRM, it is expected that the number of participants, in D2DI activites, increase in order to be suitable with the vision and the mission of D2DI.

\section{Crafting the Customer Interface}

This stage of design discusses about the interface design on the website which is going to be made. This interface design uses the 7C's framework guidelines, whcih is:

Table 5: Seven Elements of Interface Design

\begin{tabular}{|c|c|c|}
\hline 7C Framework & Variable & Features \\
\hline \multirow[t]{5}{*}{ Context } & Functional & $\begin{array}{l}\text { (1) The main menu consists of Home Page, About D2DI, Articles, } \\
\text { Contact Us, and Member Areas. } \\
\text { (2) Menu Footer consists of Copyright. }\end{array}$ \\
\hline & - Section beakdown & \\
\hline & - Linking Structure & $\begin{array}{l}\text { There are several links that can be accessed, for example: Facebook dan } \\
\text { Twitter, if it is clicked, it will be directed to Facebook or Twitter. }\end{array}$ \\
\hline & - Navigation tools & - The feature of searching the products and SME'S name. \\
\hline & Aesthetic & $\begin{array}{l}\text { (1) The website background uses white color. } \\
\text { (2) The Header uses greyish blue. } \\
\text { (3) The Footer uses black color. }\end{array}$ \\
\hline \multirow[t]{2}{*}{ Content } & Offering Mix & $\begin{array}{l}\text { (1) In the page of SME'S Product, there are detailed informations, } \\
\text { like the product's name and the category of the products, SME'S } \\
\text { categories, and prices, } \\
\text { (2) In the page of About SME'S, there is detailed information about the } \\
\text { SME'S data. }\end{array}$ \\
\hline & Appeal mix & $\begin{array}{l}\text { (1) In terms of cognitive, in the Home page, it is showed the } \\
\text { promotions provided by the SME'S. } \\
\text { (2) In terms of emotional, the forum feature, live chat, testimonials, and } \\
\text { review are provided. }\end{array}$ \\
\hline Community & & Forum, Facebook and Twitter. \\
\hline \multirow[t]{3}{*}{ Customization } & Personalization & - Registration feature. \\
\hline & Tailoring by site & $\begin{array}{l}\text { (1) For the visitors, the website provides general, statistic, and } \\
\text { registration menu features. }\end{array}$ \\
\hline & & $\begin{array}{l}\text { (2) For SME'S, there are the feature to change the SME'S data, forum, } \\
\text { change data product, change data activity, testimonial, password } \\
\text { change, also log out. }\end{array}$ \\
\hline \multirow[t]{2}{*}{ Communication } & Broadcast & Question and Answer, Menu About D2DI, Menu About SME’S. \\
\hline & Interactive & $\begin{array}{l}\text { Social network community, there are Facebook and Twitter, there is live } \\
\text { chat, forum, SME'S testimonial, Product review. }\end{array}$ \\
\hline Connection & & There is link for internal and external. \\
\hline Commerce & & The website visitors can do the registration for activity in D2DI. \\
\hline
\end{tabular}

\section{Budget Cost}

The Plan Cost of Implementing E-marketing Technology cost are modem (Wifi): 306.000 rupiah/ month. Hosting + Domain: 599.000 rupiah/year. Maintenance Website: 150.000 rupiah/month. Administrator Salary: 2.500.000 rupiah/month.

\section{CONCLUSION}

After conducting the analysis and the design of e-marketing website from Dare to Dream Indonesia community, the resolutions that can be concluded are: (1) The application of e-marketing system based on website on D2DI community, can be a solution to help the community in showing the product and service informations, which is owned completely and actually, so that it can fulfill the needs of customers for informations all this time. (2) From the result of situation analysis, the right strategy to be applied by D2DI Community is Market penetration strategy, which is by expanding the market share, so it can attract new customers, by using the website as the marketing media. (3) The application of the strategy 
and the implementation of internet-based e-marketing are the supporting system of the marketing system completely, and it is not the substitute of the old marketing system. (4) From the result of Market Opportunity Analysis (MOA), the segment which becomes the main target, is the SME'S that are located in Jabodetabek areas. The Differentation and Positioning strategies are locating their websites as a site that providing facilitations of online activity's registration. (5) E-marketing strategy that is implemented on the website features, are: Activity Registration, Live Chat with Yahoo! Messenger, Facebook link, Twitter link, Registration, Comments, Testimonials, Review, and Products Catalogue.

The suggestions from the writer to support the marketing process and further development from e-marketing website on D2DI community, are: (1) To form an organization structure. (2) The relevance of the website that is designed right now, should be adjusted for the future, because the website is design in today's condition. (3) Evaluation is needed after e-marketing is implemented, there are several methods of evaluations, one of them is using the balance score card method.

\section{REFERENCES}

[1] J. Strauss and R. Frost, E-Marketing (5th ed.), New Jersey: Prentice-Hall, 2009.

[2] M. Fisher dan P. Jaworski, Internet Marketing: Building Advantage in Network Economy, 2nd ed., New York: McGraw-Hill, 2003.

[3] F. R. David, Strategic Management - Concept and Cases, 13th ed., New York: Prentice Hall. 